\title{
Anti-Giardial Activity of Chloroformic Extract of Tanacetum parthenium and Artemisia annua in vitro
}

\author{
Shirzad Gholami ${ }^{1}$, Mohammad Azadbakht ${ }^{2}$, Hajar Ziaei Hezarjaribi ${ }^{3}$, Bahman Rahimi-Esboei ${ }^{3}$ \\ ${ }^{1}$ Molecular and Cell Biology Research Center \& Toxoplasmosis Research Center, Mazandaran University of Medical Sciences, Sari, Iran. \\ ${ }^{2}$ Department of Pharmacognosy, School of Pharmacy, Mazandaran University of Medical Sciences, Sari, Iran. \\ ${ }^{3}$ Department of Parasitology and Mycology, School of Medicine, Mazandaran University of Medical Sciences, Sari, Iran.
}

Received: 21 Nov 2013

Revised : 12 Jan 2014

Accepted: 20 Jan 2014

Corresponding Authors:

Hajar Ziaei Hezarjaribi

Department of Parasitology and

Mycology, School of Medicine,

Mazandaran University of Medical

Sciences, Sari, Iran.

E-mail: ziaei2000@yahoo.com

\begin{abstract}
Background: Giardiasis is a one of the most prevalent intestinal parasitic diseases in human, treatment of this disease through medicinal plants is very important since parasite resistance to chemical drugs exists. Thus, in this study, the in vitro anti-giardial activity of chloroformic extract of Tanacetum parthenium and Artemisia аппиа on cyst and trophozoite of Giardia lamblia were separately investigated.
\end{abstract}

Materials and Methods: In this experimental study chloroformic extracts of Artemisia апnиa and Tanacetum parthenium on cyst and trophozoite of G. lamblia in vitro were prepared in $1,10,50$ and $100 \mathrm{mg} / \mathrm{ml}$ concentrations for 5, 10, 30, 60 and $180 \mathrm{~min}$. Purified cysts were used for encystations and culture in TYI-S-33 medium. Then, $2 \mathrm{ml}$ of each solution was placed in test tubes, to which 10,000 washed cysts and trophozoites were added. The contents of the tubes were gently mixed and incubated. The percentages of dead parasites were determined by counting 500 cysts. Non treated parasites were considered a control group in each experiment and the viability of the parasites checked with Eeosin staining and statistical analysis were done.

Results: The results showed that chloroformic extracts of A. апnиa at $100 \mathrm{mg} / \mathrm{ml}$ concentration affected on Gardia cyst $86 \%$ and $100 \%$ trophozoite after 1 hour. $T$. parthenium at $50 \mathrm{mg} / \mathrm{ml}$ concentration killed cysts $(83 \%)$ and trophozite $(100 \%)$ after 1 hour, respectively. $T$. parthenium chloroformic extract had a better effect on cyst and trophozoite of Giardia at $50 \mathrm{mg} / \mathrm{ml}$ after 1 hour exposure than $A$. аппиа extract.

Conclusion: According to this study, A. апnиa and T. parthenium chlorofomic extracts could be considered as a more effective anti-giardial agent. Chloroformic extract of T. parthenium was also shown the anti-giardial activity compared with A. аппиа and control groups at all exposure times. Therefore, in the future research using these plants are recommended against Giardia in low concentration in the in vivo, also to find fractions of the pharmacological effects of these plants.

Keywords: Giardia lambelia; Chlorofomic extract; Artemisia annua; Tanacetum parthenium; Cyst; Trophozoite

Please cite this article as: Gholami SH, Azadbakht M, Ziaei Hezarjaribi H, Rahimi-Esboei B. Anti-Giardial Activity of Chloroformic Extract of Tanacetum parthenium and Artemisia annua in vitro. Res Mol Med. 2014; 2 (1): 46-51.

\section{Introduction}

Giardiasis is a one of the most prevalent intestinal parasitic infection in human, caused by the flagellate protozoan Giardia lambalia, with worldwide distribution and high rates in Mediterranean countries as well as in north of Iran (1-3). The emergence and spread of Giardiasis in human population is anincreasing problem around the world, especially in developing countries. Giardiasis has been also included as "Neglected Disease" by WHO, but it is not reported by many countries of the world. Based 
on research and increasing knowledge of the Giardia genome will improve our understanding of contamination source, transmission routes and features contributing to human illness (4-7).

Cyst and trophozoite are two distinct forms of the parasite; cysts are dormant forms responsible for the transmission of Giardiasis. They are excreted from an infected host with the feces and are exceptionally hardy and capable of tolerating extremes of $\mathrm{pH}$ and temperature. Transmission to humans usually occurs through the ingestion of cysts in contaminated water or food or via direct fecal-oral contact. The trophozoites are the vegetative form of Giardia (1-2, 5).Prevalence rates range from $2-7 \%$ in developed countries and $20-30 \%$ in most developing countries. Prevalence of $G$. lamblia in Iran almost is $10.9 \%$. The CDC estimates that there are upwards of 2.5 million cases annually (5). There is no abundant evidence for the pathogenic potential of Giardia but they are able to colonize and rapidly replicate in the gastrointestinal tract as well as cause gastrointestinal symptoms. Children are more frequently affected than adults, although all ages are may display symptoms ranging from mild diarrhea, Flatulence, anorexia, crampy abdominal pains, and epigastric tenderness to steaorrhea and full blow malabsorption syndrome and extra intestinal symptoms, such as fever, maculopapular rash, pulmonary infiltrates, lympha denopathy, polyarthritis and urticarial (2-3).

For the treatment of Giardiasis Metronidazole as the first choice and other drugs; Tinidazole, Albandazole, Furazolidone are also used (8-11). Undesirable side effects and failures in treatment and drug resistance are frequently reported (5-9). For example side effects of Metronidazole include nausea, loss of appetite, vomiting, diarrhea, lethargy, weakness, anemia, blood in the urine, head tilt, seizures, disorientation, and stumbling. It may also cause liver disease, which can result in yellowing of the gums, skin, and eyes. Damage to nerves is also possible, and the mutagenic effects of this drug in some bacteria and animal models were confirmed (8, 12-14).

Therefore, in the recent studies has been paid to extracts derivates from plants used in traditional medicine, because in the current decade, traditional systems of medicine have become a topic of global importance. Current estimates suggest that, in many developing countries, a large proportion of the population relies heavily on traditional practitioners and medicinal plants to meet primary health care needs (15-17). Concurrently, many people in developed countries have begun to turn to alternative or complementary therapies, including medicinal herbs assurance of the safety, quality, and efficacy of medicinal plants and herbal products has now become a key issue in developed and in developing countries.
In the similar studies has been suggested to identify the compounds responsible for the anti-giardial activities in the chloroform leaf extracts of P. betle and $P$. chaba (17-19).

According to current research and so, isolated bioactive compounds from plants were utilized against a wide range of microorganisms particularly parasites. Among these plants, Allium and Artemisia spp. has an undeniable portion and a plenty of researches were carried out in order to study on impact of this massively valuable plant. Artemisia апnиa, also known as annual wormwood or Sweet Annie, belongs to the family Asteraceae. Its activity against malaria parasites in primate models was demonstrated (20-21), but Artemisinin, by Chinese scientists were isolated and characterized of the active anti-malarial principle in $1972(20,22) . T$. parthenium is a perennial herbaceous essential oil bearing plant belongs to Asteraceae family. The species of genus Tanacetum have been used as medicinal plants for over 2000 years (23).

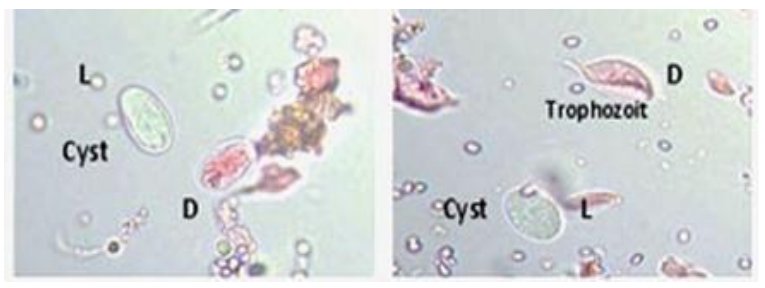

Figure 1. Cyst and Trophozoite of G. lamblia, died (D) and viable (L) cyst excluded the eosin stain

However, a combination treatment for Giardia, as part of the control approach to protozoan infections should be investigated further $(15,21,24)$. Due to high prevalence of Giardiasis, plan diversity and the geographic situation of the Mazandarn province, north of Iran, the use of medicinal plants in the treatment of parasitic infections especially intestinal parasitic is are necessary. Thus, in this study, the in vitro anti-giardial activity of chloroformic extract of $T$. parthenium and A. annua on cyst and trophozoite of $G$. lamblia were investigated separately.

\section{Materials and Methods}

Purification of $G$. lamblia cysts

G. lamblia cysts were collected from faces samples of patients from different hospitals of Mazandaran University of Medialcal Sciences. All specimens were processed immediately after arrival, ordinarily within $48 \mathrm{~h}$ after excretion. By combining the sucrose flotation method a highly purified cyst suspension was achieved by a simplified sucrose gradient method. Stools were broken up in tap water and filtered through a 300 urn filter. $3 \mathrm{ml}$ of the fecal suspension were layered on $3 \mathrm{ml}$ of $0.85 \mathrm{M}$ sucrose and centrifuged 
at $600 \mathrm{rpm}$ for $10 \mathrm{~min}$ at $4{ }^{\circ} \mathrm{C}$. The cysts at the sucrose-water interface were aspirated with a Pasteur pipette and washed 3 times with water. Washed cysts were carefully added to the top of a discontinuous density gradient, consisting of two 3-ml laves of O-85 and $0.4 \mathrm{M}$ sucrose. After centrifugation at $600 \mathrm{rpm}$ for $10 \mathrm{~min}$ at $4{ }^{\circ} \mathrm{C}$ cysts concentrated at the $0.85-0.4 \mathrm{M}$ sucrose interface were collected and washed again. Purified cysts were resuspended in distilled water and stored at $4{ }^{\circ} \mathrm{C}$ for a maximum of 3 ysprior to use (11, 29).

Excystation of $G$. lamblia cysts and Culture methods At this stage Bingham and Meyer (1979) method were used for excystation procedure (25). One volume of purified cyst suspension was added to 9 volumes of induction solution, aqueous hydrochloric acid $(\mathrm{pH} 2)$, and the preparation was incubated at 37 ${ }^{\circ} \mathrm{C}$ for one hour. After centrifugation at $600 \mathrm{rpm}$ for $10 \mathrm{~min}$ at room temperature, the supernatant was removed and the pellet was inoculated into excystation medium. Initial experiments demonstrated that survival of most of the primary cultures could be favorably affected by the addition of bile and by increasing the serum component to $20 \%$ (26). Therefore the excystation medium used consisted of filter-sterilized TYI-S-33 culture medium, with bovine bile added $(11,27)$, supplemented with $20 \%$ heat inactivated fetal calf serum. Screw capped borosilicate glass culture tubes containing $8 \mathrm{ml}$ of the medium, supplemented with penicillin (500 iu/ml) and streptomycin $(500 \mathrm{ug} / \mathrm{ml})$, and were incubated at $37^{\circ} \mathrm{C}$ in a slant.

Table 1. Effect of chloroformic extract of Artemisia апnиa on G. lamblia cyst and trophozoite at different times.

\begin{tabular}{ccccccccccc}
\hline & \multicolumn{1}{c}{$1 \mathrm{mg} / \mathrm{ml}(\%)$} & \multicolumn{2}{c}{$10 \mathrm{mg} / \mathrm{ml}(\%)$} & \multicolumn{2}{c}{$50 \mathrm{mg} / \mathrm{ml}(\%)$} & \multicolumn{2}{c}{$100 \mathrm{mg} / \mathrm{ml}(\%)$} & \multicolumn{2}{c}{ Control (\%) } \\
\hline & cyst & Trophozoite & cyst & Trophozoite & cyst & Trophozoite & cyst & Trophozoite & cyst & Trophozoite \\
\hline $1 \mathrm{~min}$ & 67 & 65 & 69 & 67 & 71 & 67 & 73 & 72 & 3 & 9 \\
$5 \mathrm{~min}$ & 69 & 78 & 75 & 79 & 77 & 84 & 79 & 86 & 3 & 9 \\
$30 \mathrm{~min}$ & 75 & 83 & 79 & 87 & 82 & 88 & 78 & 92 & 5 & 9 \\
1 hour & 77 & 89 & 79 & 92 & 84 & 96 & 86 & 100 & 7 & 11 \\
\hline
\end{tabular}

\section{Preparation of plants chloroformic extract}

The plants were dried under shade, and powdered mechanically using a commercial electrical blender. To obtain the chloroformic extract, $70 \mathrm{~g}$ of dry powder was added to $350 \mathrm{ml}$ of pure chloroform and mixed gradually for $1 \mathrm{~h}$ using a magnetic stirrer. The obtained solution was left at room temperature for 24 $\mathrm{h}$. The solution was stirred again and filtered. Then, the solvent was removed by evaporation in a rotating evaporator at $40{ }^{\circ} \mathrm{C}$. The remaining semisolid material was freeze-dried and placed into a sterile glass container and stored at $4{ }^{\circ} \mathrm{C}$ for further use $(11,28)$.

Effectiveness of plants extracts on cysts and trophozoites of $G$. lamblia

Four concentrations $\left(1,10,50\right.$, and $\left.100 \mathrm{mg} \mathrm{ml}^{-1}\right)$ of the plants choloroformic extract were applied for 5, 10, 30 and $60 \mathrm{~min}$. To make the extracts solution at 1 , 10,50 and $100 \mathrm{mg} \mathrm{ml}-1$ concentrations, $0.01,0.1$, 0.5 , and $1 \mathrm{~g}$ of each dried extract were dissolved in $10 \mathrm{ml}$ of normal saline, respectively. Then, $2 \mathrm{ml}$ of each solution was placed in test tubes, to which 10,000 washed cysts and trophozoites was added. The contents of the tubes were gently mixed and incubated at $37{ }^{\circ} \mathrm{C}$ for $5,10,30$, and $60 \mathrm{~min}$. At the end of each incubation time the upper phase was carefully removed so as not to interrupt the parasites. Two milliliters of $0.1 \%$ eosin stain added to the remaining settled cysts and trophozoites and mixed gently. The upper portion of the solution was discarded after $15 \mathrm{~min}$ of incubation and the remaining pellet smeared on a glass slide, covered with a cover glass and examined under a light microscope. The percentages of dead parasites were determined by counting 500 cysts. Non treated parasites were considered a control group in each experiment, which was performed in triplicate. The third group was given metronidazole $(0.2 \mathrm{mg} / \mathrm{ml})$ as above and the fourth group was given normal saline alone (Control group). (DMSO)

\section{Viability tests}

Eeosin stain with the concentration of $0.1 \%$ ( $1 \mathrm{~g}$ of eosin powder in $1000 \mathrm{ml}$ distilled water) was used to check the viability of the parasites. Fifteen minutes after exposure to the stain the cysts and trophozoites with no absorbed dye were considered potentially viable, otherwise, they were (Figure 1) (11).

\section{Statistical analysis}

Statistical analysis was performed by means of oneway ANOVA (analysis of variance) considering a 
level of significance of $95 \%(\mathrm{P}<0.05)$, with SPSS software.

\section{Results}

The results of different concentrations of chloroformic extract of A. аппиа and $T$. parthenium against $G$. lamblia cyst and trophozoite in different times are summarized in Tables 1 and 2. Chloroformic extracts of A. апnиa at $10 \mathrm{mg} / \mathrm{ml}$ and $100 \mathrm{mg} / \mathrm{ml}$ concentration had affected on Giardia cyst $96 \%, 99 \%$ and trophozoit $(100 \%)$ after 3 hour, whereas the chloroformic extract of $T$. parthenium at $1 \mathrm{mg} / \mathrm{ml}$ and $10 \mathrm{mg} / \mathrm{ml}$ concentration killed $97 \%, 99 \%$ on cyst and at $1 \mathrm{mg} / \mathrm{ml} 100 \%$ on trophozite after 3 hour, $50 \mathrm{mg} / \mathrm{ml}$ effected $100 \%$ trophozite after one hour, respectively. Therefore, $T$. parthenium chloroformic extract had a better effect on cyst and trophozoite of Giardia at 10 $\mathrm{mg} / \mathrm{ml}$ after 3 hour exposure than $A$. аппиа extract. Choloroformic extract of $A$. апnиа could maximum effect $100 \%$ on trophozoite of Giardia in $1 \mathrm{mg} / \mathrm{ml}$ concentration after 3 hour and $100 \mathrm{mg} / \mathrm{ml}$ concentration after one hour.

Table 2. Effect of chloroformic extract of $T$. parthenium on G. lamblia cyst and trophozoite at different times.

\begin{tabular}{|c|c|c|c|c|c|c|c|c|c|c|}
\hline & \multicolumn{2}{|c|}{$1 \mathrm{mg} / \mathrm{ml}(\%)$} & \multicolumn{2}{|c|}{$10 \mathrm{mg} / \mathrm{ml}(\%)$} & \multicolumn{2}{|c|}{$50 \mathrm{mg} / \mathrm{ml}(\%)$} & \multicolumn{2}{|c|}{$100 \mathrm{mg} / \mathrm{ml}(\%)$} & \multicolumn{2}{|r|}{ Control } \\
\hline & Cyst & Trophozoite & Cyst & Trophozoite & Cyst & Trophozoite & Cyst & Trophozoite & Cyst & Trophozoite \\
\hline $1 \mathrm{~min}$ & 46 & 40 & 48 & 49 & 56 & 51 & 58 & 53 & 3 & 8 \\
\hline $5 \mathrm{~min}$ & 69 & 53 & 71 & 56 & 73 & 58 & 75 & 58 & 3 & 9 \\
\hline $30 \mathrm{~min}$ & 74 & 70 & 76 & 73 & 78 & 75 & 80 & 78 & 3 & 9 \\
\hline 1 hour & 79 & 98 & 81 & 99 & 83 & 100 & 87 & 100 & 4 & 9 \\
\hline
\end{tabular}

The results of present study indicated that chlorofomic extracts of $A$. апnиa showed a high activity effect on trophozoite in $100 \mathrm{mg} / \mathrm{ml}$ at one hour and $99 \%$ on cysts in $100 \mathrm{mg} / \mathrm{ml}$ after 3 hour exposure. T. parthenium revealed a high activity on trophozoite of Giardia at $50 \mathrm{mg} / \mathrm{ml}$ after 1 hour $(100 \%)$ and on cyst after 3 hour (Tables 2). No statistically significant differences $(\mathrm{P}>0.05)$ were observed between chloroformic extract of the $A$. annua and T.parthenium at concentration of $1 \mathrm{mg} / \mathrm{ml}$, $10 \mathrm{mg} / \mathrm{ml}$ and $50 \mathrm{mg} / \mathrm{ml}$ on cyst after 3 hour and trophozoite of Giardia, but at concentrations of 50 and 100 after one hour $(\mathrm{P}<0.05)$. As a result, chloroformic extract of $T$. parthenium in $10 \mathrm{mg} / \mathrm{ml}$ and A. аnnua in $100 \mathrm{mg} / \mathrm{ml}$ concentrations on the cyst and trophozoite of Giardia had a greater effected at 3 hour. T. parthenium in $50 \mathrm{mg} / \mathrm{ml}$ after one hour on trophozoite of Giardia was affected, whereas, similar effected was found using A. аппиа on $100 \mathrm{mg} / \mathrm{ml}$ after one hour.

\section{Discussion}

G. lamblia is common intestinal protozoan parasites with severe symptoms of diarrhea and sickness can be infected infants, elderly and immuno-compromised individuals, $(9,20)$. The necessity to investigate new, safe, and effective agents for the treatment of Giardiosis is imperative due to the side effects and resistance of the reference drugs $(9,20,30)$. Plants used for the treatment of gastrointestinal disorders, such as diarrhea and dysentery, raise the possibility of new alternative therapies (20). The present study evaluated the anti-giardial activity of chlorofomic aqueous extracts of 2 plants (A. annua and $T$. parthenium) used leaves and stems as edible and medicinal plants in Northern Iran. The results of our study indicated that chlorofomic extracts of A. аппиа and $T$. parthenium showed a high activity effect on trophozoite and cyst in $50-100 \mathrm{mg} / \mathrm{ml}$ between $1-3$ hour exposures. In this study we analyzed the antigiardial activity of this plant and $T$. parthenium as new medical herbs, whereas, A. апnиa is well known for anti-Malarial and anti-Hemorrhoid activity (21, 23).

Many studies have investigated the in vitro and in vivo effect of various plants on G. lamblia cysts and trophozoites. (15-16, 29-30) showed the effects of different plants, fractions and/or purified compounds against $G$. lamblia cyst and trophozoite and comparing it with the present data (15-17). Rahimiesboei et al. 2012 reported $97 \%$ and $100 \%$ antigiardial activity for $100 \mathrm{mg} / \mathrm{ml}$ of $A$. аппиа extract on cyst and trophozoite in vitro (29).

Sadjjadi et al 2006 was shown that giardiacidal activity at $4{ }^{\circ} \mathrm{C}$ after 3 hours for lemon juice, Vinifer and vinegar were $18.9 \%, 12.8 \%$, and $28.4 \%$, at $24{ }^{\circ} \mathrm{C}$, $28.3 \%, 16.2 \%$, and $40.6 \%$, respectively (15). Calzada et al. 2006 also reported the anti-protozoal activity of 27 crude methanolic extracts derived from 26 plants (24 genera in 20 families) used in Mexican traditional medicine for treatment of diarrhea and dysentery (30). They found that Dorstenia contrajerva, Senna villosa and Ruta chalepensis were the most active against $G$. lamblia with IC50 $<38 \mathrm{~g} / \mathrm{ml}$. In other 
researches Geranium mexicanum, Cuphea pinetorum, Helianthemum glomeratum, and Rubus coriifolius have been found to be effective on cyst and trophozoite of $G$. lamblia in vitro $(16,30)$.

Results of the present study demonstrate the A. annua and $T$. parthenium chlorofomic extracts could be considered as more effective than the majority of other plant extracts and their active principles. chloroformic extract of $T$. parthenium has also shown the anti-giardial effect to compare with A.annua and control groups at all exposure times. Obviously after 3 hour A.annua had a similar effect to $T$. parthenium in $1 \mathrm{mg} / \mathrm{ml}$ and $10 \mathrm{mg} / \mathrm{ml}$ concentration on trophozoite of Giardia. T. parthenium after one hour had $100 \%$ anti-giardial activity against cyst and against trophozoites in $10 \mathrm{mg} / \mathrm{ml}$ concentration. But as whole the effectiveness of $T$. parthenium was so more acceptable than A. аппиа. Therefore, in future research, using these plants is recommended against in vivo growth of Giardia with concentrations of 200 $\mathrm{mg} / \mathrm{ml}$ and $400 \mathrm{mg} / \mathrm{ml}$, also research to find fractions of the pharmacological effects of these plants.

Although, a rapid and complete giardiacidal effect with no local or systemic side effects and also low cost are some properties of an ideal anti-giardiacidal solution. From this point of view, no ideal giardiacidal agents have been described yet. The present study provides evidence of an inhibitory activity, ranging from moderately inhibited to killing by the choloroformic extract from A. annua and $T$. parthenium against $G$. lamblia. It is probably worthwhile to purify these active extracts to identify specific compounds responsible for the activities. This result enhances the ethno botanical uses of the plant as anti-diarrheal in cases associated with Giardiasis. To find an effective chemical composition, further investigations regarding the mode of action and other related pharmacological studies such as in vivo study, drug formulation and clinical trials are recommended.

\section{Acknowledgement}

The authors would like to express their deep thanks to all lab staff of Department of Parasitology and Mycology and Department of Pharmacognosy and Biotechnology, Mazandaran University of Medical Sciences, Sari, Iran, epically Shaban Gohardehi, Mahbobeh Hossini, and Reza Bastani for helping the study. The results obtained in this article are obtained freom a student thesis, which was supported by grant 92-74 from the Research Administration Department of Mazandaran University of Medical Sciences, Sari, Iran, and conducted in Cellular and Molecular Biology Research center.

\section{References}

1. Flannagan PA. Giardia: diagnosis, clinical course and epidemiology: a review. Epidemiol Infect. 1992; 109: 1-22. PMID: 1499664

2. Thompson RCA, Reynoldson JA, Mendis AHW. Giardia and giardiasis. Adv Parasitol. 1993; 32: 71-160. PMID: 8237618

3. Sharif M, Ziaei H, Azadbakht M, Gholami S, Khalilian AR. Relationship between Giardiasis an amount of Zinc, Iron elements in babies below 12 years old. J Gorg Univ Med Sci. 2005; 14: 87-91.

4. Gholami Sh, Kyanyan H, Mobedi I, et al. Intesteinal Protozoan Infections in cattle breeders in rural regions of Mazandaran province in 2003. J Mazandaran Univ Med Sci. 2005; 45 (14): 5160

5. Lane S, Lloyd D. Current trends in research into the waterborne parasite Giardia. Crit Rev Microbiol. 2002; 28 (2): 123-47. PMID: 12109771

6. Babaei Z, Oormazdi H , Akhlaghi L, Rezaie S, Razmjou E, Soltani- Arabshahi SK, et al. Molecular characterization of the Iranian isolates of Giardia lamblia: application of the glutamate dehydrogenase gene. Iranian J Publ Health. 2008; 37 (2): 75-82.

7. Savioli L, Smith H, Thompson A. Giardia and Cryptosporidium join the 'Neglected Diseases Initiative'. Trends in Parasitology 2006; 22 (5): 203-208. PMID: 16545611

8. Tracy JW, Webster Jr, LT. Drugs used in the chemotherapy of protozoal infection. In: Hardman, J.G, Limbird, L.E. (Eds.), Goodman \& Gilman's The Pharmacological Basis of Therapeutics, ninth ed. McGraw-Hill, New York, 1996. pp. 987-1008.

9. Alizadeh A, Ranjbar M, Kashani KM, Taheri MM, Bodaghi M. Albendazole versus metronidazole in the treatment of patients with giardiasis in the Islamic Republic of Iran. East Mediterr Health J. 2006; 12: 548-554. PMID: 17333792

10. Moerch K, Hanevik K, Robertson LJ, Strand EA, Langeland N. Treatment-ladder and genetic characterization of parasites in refractory giardiasis after an outbreak in Norway. J Infect. 2008; 56: 268-273. PMID: 18328567

11. Costa Brandelli CL, Giordani RB, De Carli GA, Tasca T. Indigenous traditional medicine: in vitro anti-giardial activity of plants used in the treatment of diarrhea. Parasitol Res 2009; 104: 1345-1349. PMID: 19153765

12. Johnson PJ. Metronidazole and drug resistance. Parasitology Today 1993; 9: 183-186. PMID: 15463749

13. Lemee V, Zaharia I, Nevez G, Rabodonirina M, Brasseur P, Ballet JJ, Favennec L. Metronidazole and albendazole susceptibility of 11 clinical isolates of Giardia duodenalisfrom France. Journal of Antimicrobial and Chemotherapy 2000; 46 (5): 819-21. PMID: 11062206

14. Voolmann Y, Boreham PFL. Metronidazole resistant Trichomonasvaginalis in Brisbane. Medical Journal of Australia 1993; 159- 490. PMID: 8412928

15. Sadjjadi S M, Rostami J and Azadbakht M. Giardiacidal Activity of Lemon Juice, Vinifer andVinegar on Giardia intestinalis Cysts. Southeast Asian J Trop Med Public Health 2006; 37: 24-27. PMID: 17547046

16. Calzada F, Yépez-Mulia L, Aguilar A. In vitro susceptibility of Entamoebahistolytica and Giardia lamblia to plants used in 
Mexican traditional medicine for the treatment of gastrointestinal disorders. J Ethnopharmacol 2006; 108: 367-370. PMID: 16846708

17. Barbosa E, Calzada F, Camposb R. In vivo anti-giardial activity of three flavonoids isolated of some medicinalplants used in Mexican traditional medicine for the treatment of diarrhea. Journal of Ethnopharmacology 2007; 109 (3): 552-554. PMID: 17052875

18. Sawangjaroen N, Subhadhirasakul S, Phongpaichit S, Siripanth $\mathrm{C}$, Jamjaroen K, Sawangjaroen k. The in vitro anti-giardial activity of extracts from plants that are used for self-medication by AIDS patients in southern Thailand. Parasitol Res 2005; 95: 17-21. PMID: 15614584

19. Yeung H-C. Handbook of Chinese herbs and formulas. Institute of Chinese Medicine, Los Angeles 1985.

20. Amaral FMM, Ribeiro MNS, Barbosa-Filho JM, Reis AS, Nascimento FRF, Macedo RO. Plants and chemical constituents with giardicidal activity. Rev Bras Farmacogn 2006; 16: 696-720.

21. Azadbakht M, Azadbakht MS. Five prevalent anti-protozoal herbal drugs. Journal of Mazandaran University of Medical Sciences 2008; 18 (67): 118-132.

22. Ekanem AP, Brisibe EA. Effects of ethanol extract of Artemisia annua L. against monogenean parasites of Heterobranchuslongifilis. Parasitol Res 2012; 106 (5): 1135-9. PMID: 20165872

23. Blanke CH, Naisabha GB, Balema MB, Mbaruku GM, Heide L, Muller MS. Herba Artemisia eannuae tea preparation compared to sulfadoxine-pyrimethamine in the treatment of uncomplicated falciparum malaria in adults: a randomized double-blindclinical trial. Trop Doct 2008; 38: 113-116. PMID: 18453510

24. Sharif M, Ziaei H, Azadbakht M, Daryani A, Ebadattalb A, Rostami M. Effeet of methanolic extract of Artemisia auchori and Camellia sinansis on Leishmania major (in vitro). Turk Sci 2006; 36 (6): $365-369$.
25. Bingham AK, Meyer EA. Giardia excystation can be induced in vitro in acidic solutions. Nature 1979; 277: 301-302. PMID: 33337

26. Laarman JJ, Hautus M, Abdillahi H. Isolation of stocks of Giardia lamblia from stools and their use in the determination of specific immunoglobulins in patient sera. Tropical and Geographical Medicine 1986; 38: 320.

27. Keister DB. Axenic culture of Giardia lamblia in TYI-S-33 medium supplemented with bile. Trans. R. Soc. Trop. Med. Hyg 1983; 77: 487-488. PMID: 6636276

28. Omidbeigi, R. Production and Processing of Medicinal Plants, Tarbiat Modares University Press, Tehran, Iran 2007; 256-267.

29. Rahimi-Esboei B, Gholami Sh, Azadbakht M, ziaei H. Effect of Hydroalcholic extract of Artemisia annua on cysts of Giardia lamblia in vitro. Mazand Univ Med Sci 2012; 22 (90): 72-80.

30. Calzada F, Yépez-Mulia L, Aguilar A. In vitro susceptibility of Entamoeba histolytica and Giardia lamblia to plants used in Mexican traditional medicine for the treatment of gastrointestinal disorders. J Ethnopharmacol 2006; 108: 367-370. PMID: 16846708

31. Maraghi S, Mosayeb B. Study of anti-Giardial effect of barberry stem bark extract in comparison with Metronidazole in mouse. Scientific Medical Journal of Ahwaz University of Medical Sciences 1999; (25): 32-26. 